\title{
The Causal Relationship of Microfinance and Economic Development: Evidence from Transnational Data
}

\author{
Kerstin Lopatta ${ }^{1} \&$ Magdalena Tchikov ${ }^{1}$ \\ ${ }^{1}$ Accounting and Corporate Governance, Carl von Ossietzky University Oldenburg, Germany \\ Correspondence: Magdalena Tchikov, Accounting and Corporate Governance, Carl von Ossietzky University \\ Oldenburg, Ammerlaender Heerstrasse 114-118, D-26129 Oldenburg, Germany. Tel: 49-441-798-4164.
}

Received: June 29, 2017

Accepted: July 13, 2017

Online Published: July 16, 2017

doi:10.5430/ijfr.v8n3p162

URL: https://doi.org/10.5430/ijfr.v8n3p162

\begin{abstract}
The purpose of this study is to investigate the so far underexamined statistical causality of the relationship between microfinance and economic development. For a representative transnational dataset covering the period $1995-2012$ we instrumentalize pairwise vector autoregressive (VAR) estimation models and the Granger approach. We utilize prevalent microfinance institutions' (MFI) performance indicators as measures of microfinance as well as relevant economic development indicators that not only measure economic and capital growth but also poverty, income inequality and labor participation. We find bidirectional causal interactions between both MFIs' social and financial performance and economic development. Based on our results important implications for microfinance theory, research and practice can be derived. Future empirical research should account for the statistical causality between microfinance and economic development. In practice, purposeful and progressive action that considers the directions of causality between microfinance and economic development verified within our study should be taken to promote economic growth and poverty alleviation.
\end{abstract}

Keywords: microfinance, social performance, financial performance, economic development, Granger causality

\section{Introduction}

Microfinance promises poverty alleviation, financial systems and economic development through serving people who are usually excluded from the formal banking sector (Morduch, 1999). Microfinance institutions (MFIs) are financial and social intermediaries that unite the characteristics of both formal and informal financial systems. On the one hand, they establish and improve the quality of (developing) financial sectors by offering access to credit for those at the bottom of the pyramid (Kamath, 2009). Then, by applying qualitative credit risk assessment approaches that consider factors such as clients' characters, willingness to repay and social standing (Tonelli \& Dalglish, 2011) MFIs contribute to the improvement of economic activities, productivity and ethics of repayment. The microfinance concept and MFIs thus ought to contribute to sustainable economic development by increasing not only short-term consumption levels and savings, but also education, self-employment and new businesses (Morduch, 1999).

As social enterprises that have a 'double bottom line' MFIs aim at balancing both their social and financial outcomes (Hudon \& Périlleux, 2014). Current microfinance research and practice, therefore, distinguish between MFIs' social and financial performance and proxy social performance by their outreach to poor clients. The latter is quantified by indicators such as average loan balances, number of borrowers as well as percentage of female clients (Rosenberg, 2009). MFIs' financial performance is measured by their portfolio quality, profitability and returns. Nevertheless, in theory, MFIs should operate self-sufficiently, i.e. they have to cover their expenses through interest revenues and independent of subsidies (Prior \& Argandoña, 2009; Rosenberg, 2009).

Prior literature has shown that, in fact, microfinance impacts economic development by increasing economies' capital and improving financial development (Armendáriz \& Morduch, 2010; Kamath, 2009). Then again, current research suggests that economic development affects microfinance as they utilize economic development indicators such as gross domestic product (GDP) growth and gross national income (GNI) per capita when modeling microfinance and MFIs' performance (e.g., Assefa et al, 2013; Vanroose \& D'Espallier, 2013). A clear deficiency of existing empirical studies is, however, that although they imply the causality of effects between MFIs' performance and their macroeconomic environment (e.g., Ahlin et al, 2011; Cull et al, 2015; Imai et al, 2012) they do not empirically question it on international level (Awojobi \& Bein, 2011). Still, the verification of this relationship's 
causality is of extraordinary economic importance as it is relevant for developing targeted microfinance strategies and for empirical research. In other words, in the case of a richer household that has obtained a larger loan, did the loan make the household richer or did the richer household simply have easier access to credit?

The objective of the present study is to answer this question. In particular, we aim at verifying the statistical causality between microfinance and economic development utilizing the Granger approach and transnational data. We add to current literature and research as, to the best of our knowledge, we are the first to present generalizable empirical evidence on the Granger causality between economic development and microfinance despite of practitioners' and researchers' missing common denominator with regard to the size of effects the microfinance concept has on economic development and poverty alleviation (Rajbanshi et al, 2015). Furthermore, we quantify microfinance by MFIs' performance thus assessing the MFI-specific contribution to economic development. In contrast, previous research has presented causality results based on macroeconomic aggregations of loan portfolios and capital (e.g., Imai et al., 2012; Maksudova, 2010) that do not allow the differentiation between MFIs' social and financial performance. We fill this research gap and quantify microfinance by several generally accepted MFI performance indicators namely, number of clients served, percentage of female borrowers, average loan balance, portfolio at risk, return on assets, operational self-sufficiency, and operating expenses. Then, we improve current research that has measured economic development by GDP growth and GNI (e.g., Eigbiremolen \& Anaduaka, 2014; Maksudova, 2010; Vanroose \& D'Espallier, 2013) and expand our analysis to further economic development indicators that have been found to interrelate with microfinance (e.g., Morduch, 1999). Hence, we consider not only GDP growth and lagged GNI per capita but also indicators such as poverty headcount ratio, income inequality, capital formation, labor participation as well as literacy rate. Last but not least, we base our analyses on a representative transnational dataset aggregating highly reliable MFI-specific data for 952 MFIs operating in 101 countries and for the period 1995 - 2012. We thus advance previous research that examines the causality between microfinance and economic development in individual countries (e.g., Eigbiremolen \& Anaduaka, 2014; Nwakanma et al, 2014; Sharma et al, 2014).

The remainder of the paper is organized as follows. Following this introduction, we review current theory and research on the relationship between microfinance and economic development. The third section introduces our data and methodological approach. The empirical results are presented and discussed by the fourth section. The fifth section concludes.

\section{Theoretical Background}

\subsection{Conceptual Framework}

According to Joseph Schumpeter's Theory of Economic Development (1955), banks are the key to economic development as they channel society's savings to entrepreneurs who innovate. Then, according to King and Levine (1993), the level of financial development is associated with both the rate of physical capital accumulation and real per capita GDP growth. Particularly important for developing countries is, therefore, to achieve sustainable economic growth and financial systems development as they are shown to strongly interrelate. I.e. economic growth leads to an increasing demand for financial services which then enhances financial system development (Hassan et al, 2011).

Microfinance affects economic and financial systems development through several channels. The concept contributes to allocating capital, encouraging and monitoring investments as well as motivating consumption, entrepreneurship and productivity. Microfinance, therefore, does not only add value to individual and national incomes but also to levels of physical capital accumulation, for example by facilitating and allocating savings, as well as to levels of education and employment, for example by supporting (micro-)entrepreneurs and their families.

In practice, microfinance providers offer basic financial services in limited amounts to low-income, often underemployed persons and entrepreneurs with small, informal businesses (Bank for International Settlements, 2010). Compared to formal credit, microloans are rather small, have no typical collateral, and permit unsteady repayments. As microfinance clients often lack official financial statements MFI employees assess alternative values such as their characters, social standings and willingness to repay during field visits and applying a fairly qualitative credit risk assessment approach (Tonelli \& Dalglish, 2011). Within this concept of sustainable social welfare development microfinance is specifically targeted at women (Morduch, 1999). As in developing countries they are often deficient in occupation and education women usually cannot serve with marketable loan guarantees. MFIs thus contribute to the empowerment of women by providing them with otherwise unattainable resources and supporting them to set up businesses as well as to achieving integrity and equality.

Small groups of people can also obtain microcredits. In such cases, the group members cross-guarantee each other. The microfinance concept, therefore, also accepts social relations as loan collateral. On the other hand, such 
conformations add up to a further dimension of borrowers' repayment motivation. Still, the latter might be exploited by MFIs that exaggerate their recovery and profitability targets. Additional ethical issues inherent in the microfinance concept include over-indebtedness risks that are given when MFIs lend multiple credits to the same clients without appropriately advising them. The integrity and financial independence of microfinance clients might then be jeopardized by offensive operating policies such as interest rates of 80 to 100 per cent and improper repayment schemes (e.g., Schicks, 2014). Furthermore, attracted by promises for a win-win solution from which poor clients, financial institutions and economies profit (Morduch, 1999) new and more institutions have entered and expanded the microfinance market. This has, however, also led to increasing loan amounts and a drift from poorer to wealthier clients. Restricting their efforts to qualitatively assess and monitor their risks, MFIs have refocused from the contribution to economic development to cost reduction and profitability (Assefa et al, 2013; Cull et al, 2007). That given the trade-offs between their social, ethical, financial and economical objectives MFIs' overall equation of linking capital and labor inputs into profits and social change has proven difficult to master (Cull et al, 2007) is, therefore, not surprising.

\subsection{Previous Empirical Evidence}

When reviewing current literature and research on microfinance two mainstreams can be perceived. The first stream introduces profitability analyses of MFIs' self-sufficiency and thus examines microfinance from the perspective of individual MFIs. Qualitative and quantitative research verifies the significance of regional effects on MFIs' social and financial performance (e.g., Vanroose \& D'Espallier, 2013). Age, size, lending methodology and operational costs are also shown to influence MFIs' performance and efficiency (e.g., Cull et al, 2007; Hudon \& Périlleux, 2014). Competition on the microfinance market is, however, shown to have a rather negative effect on MFIs' outreach and performance (Assefa et al, 2013). In fact, according to Cull et al (2007), institutions that have managed to achieve profitability while maintaining a significant business relationship with their original clients, i.e. the poor and low-income borrowers, thus achieving the ultimate promise of microfinance are exceptions. Although of relevance in particular for MFI practice, analyses based on MFI-individual sustainability, however, leave the long-term objectives of the microfinance concept, namely poverty alleviation, financial systems and economic development and thus the interdepending effects of its economic effectiveness unconsidered.

The second stream of microfinance literature presents macroeconomic research. The studies draw theoretical models of economic development and growth under the consideration of microfinance and its main outcome - the increase in capital stock (e.g., Armendáriz \& Morduch, 2010; Kamath, 2009). The absolute size of the effects microfinance has on economic development and poverty alleviation has, however, stayed a contentious research subject (Rajbanshi et al, 2015). Then, although due to the commercialization of the industry macroeconomic benefits such as volume increases, outreach to new clients as well as product and portfolio diversification might seem likely, these research issues are either only ambiguously verified or simply underexamined. In fact, studies by e.g., Awojobi and Bein (2011), Eigbiremolen and Anaduaka (2014) and Kamath (2009) offer empirical examinations on the macroeconomic effects of microfinance. However, these works base on data from only one country and thus face limited generalizability. MFIs' performance is also modeled as dependent on economic development (e.g., Ahlin et al, 2011; Imai et al, 2012). Current research, therefore, often implies the causality between microfinance and economic development but does not explicitly test for it. The latter is, however, of extraordinary theoretical and practical relevance. First, empirical research should account for the effects once this causality is verified. The directions of causality between microfinance and economic development should then find consideration in developing purposeful and systematic action to promote economic growth and poverty alleviation.

The limited empirical research on the causal interaction between microfinance and macroeconomic indicators includes Maksudova (2010) who quantifies microfinance by country and year averages of the growth rate of MFIs' gross loan portfolios. Macroeconomic indicators include annual growth rates of real GDP and money supply as well as increases of the ratio of private credit to GDP. For a cross-country sample comprising data for over 1400 MFIs from 102 countries and 14 years (1995 - 2009) the study proves that microfinance Granger causes GDP growth. The effects are, however, shown to differ depending on countries' development levels. The interactions between the growth rates of MFIs' gross loan portfolios and money supply as well as private credit turn out to be negative and Maksudova (2010) concludes that considering factual economic history this relationship's direction is ambiguous.

Eigbiremolen and Anaduaka (2014) also examine the Granger causality between microfinance and economic growth. They utilize MFI-level loan portfolios as a measure of microfinance and real GDP when quantifying economic growth as well as quarterly data for 11 years (1992 - 2012) and MFIs operating in Nigeria. Granger causality tests show a unidirectional causal relationship of economic growth to microfinance. That microfinance Granger causes 
GDP cannot be significantly verified. This finding is confirmed by Nwakanma et al (2014) who also analyze the causality between economic growth and microfinance for data from Nigeria. Time series for 30 years (1982 - 2011) are explored utilizing autoregressive distributed lag and Granger approaches and year-level microcredit aggregations as well as real GDP as measures of microfinance and economic growth, respectively. Still, Nwakanma et al (2014) are also not able to verify the bidirectional causality between MFIs' credit volumes and Nigeria's GDP. Similarly, Sharma et al (2014) find for India and a period of 20 years (1992 - 2012) an unidirectional Granger causal relationship from economic development as quantified by GDP to microfinance again measured by year-level microloan volumes. The study also verifies a bidirectional causal relationship of microfinance and agricultural production which Sharma et al (2014) explain by the fact that microloans are usually provided to farmers and thus to the rural sector.

Although pioneering the microfinance and economic research these analyses are not free from limitations and cannot be generalized on an international level due to their datasets and measurement approaches. The aim of the present study is, therefore, to shed light on this important economic and financial research issue and to investigate possible statistical causalities between microfinance and economic development utilizing the Granger (1969) approach, generally accepted microfinance and development measures and a large transnational dataset.

\section{Materials and Methods}

\subsection{Data and Variable Description}

In order to empirically examine the causality of microfinance and economic development we refer to the period 1995 - 2012 and quantify microfinance performance by the social and financial performance of MFIs (Rosenberg, 2009). By instrumentalizing MFIs' performance as a measure of microfinance we consider both the quantity and quality aspects of microfinance operations and thus extend previous empirical research where microfinance is quantified by aggregated microloan volumes or gross loan portfolios (Eigbiremolen \& Anaduaka, 2014; Maksudova, 2010; Nwakanma et al, 2014; Sharma et al, 2014).

We obtain financial institution-specific data for 952 MFIs from 101 countries from the Microfinance Exchange Market (MIX) database. One limitation of our dataset is given by the characteristics of MIX Market where MFIs self-report data on their annual financial statements. As MFIs have to invest their own resources for this voluntary reporting, the database might under-represent smaller microfinance providers (Maksudova, 2010). Nevertheless, as it is the most exhaustive platform including data on worldwide operating MFIs, the MIX Market database has been used by the majority of empirical studies on microfinance (e.g., Cull et al, 2007; Maksudova, 2010; Vanroose \& D'Espallier, 2013). Furthermore, the database assesses institutions' reporting quality and offers information on whether MFIs' financial statements were audited by third-party accounting firms. To ensure the reliability of our results we consequently exclude financial statements that were not audited prior to data selection (Ahlin et al, 2011). We thus further improve the quality and representativeness of our dataset as compared to previous research (e.g., Maksudova, 2010; Vanroose \& D’Espallier, 2013).

In line with the World Bank's Consultative Group to Assist the Poor (Rosenberg, 2009) as well as prior literature (e.g., Assefa et al, 2013; Cull et al, 2007), we refer to number of clients served, percentage of female borrowers, average loan balance per client, portfolio at risk, return on assets, operational self-sufficiency and operating expenses as microfinance performance measures. The first three performance indicators measure MFIs' social performance, the latter four - to their financial performance (Rosenberg, 2009). To ensure the robustness of our results we eliminate the influence of outliers by winsorizing the MFI-specific data to the 1st and 99th percentiles. In order to conduct reasonable time series tests we then aggregate the MFI performance indicators to their year and country means (Maksudova, 2010) and totals for the number of clients served, respectively (Imai et al, 2012).

Considering the mutual dependence of development parameters and in line with prior literature (e.g., Ahlin et al, 2011; Islam et al, 2015; Lopatta \& Tchikov, 2016; Schicks, 2014) we measure economic development by several economic development measures namely, poverty headcount ratio, GINI coefficient of income inequality, GDP growth, lagged GNP per capita, lagged gross capital formation, lagged labor participation rate as well as literacy rate. The measures of economic development included in our study are obtained from the World Bank's World Development Indicators (WDI). Lagged values are calculated in order to achieve better comparability between microfinance performance and economic development for the transnational dataset. Nevertheless, due to time-series data availability for some of the indicators non-lagged, absolute values had to be taken. Detailed descriptions of all variables utilized in our study are presented in Table 1: 
Table 1. Variable names and descriptions

\begin{tabular}{|c|c|c|}
\hline Name & Variable & Description \\
\hline \multicolumn{3}{|c|}{ MFIs' social performance } \\
\hline NOB & Number of clients served & $\begin{array}{l}\text { Total number of the clients served by MFIs as a ratio to countries' } \\
\text { populations }\end{array}$ \\
\hline PFB & Percentage of female borrowers & $\begin{array}{l}\text { Yearly average of the number of MFIs' female borrowers as a ratio } \\
\text { to their total active borrowers }\end{array}$ \\
\hline ALB & Average loan balance per client & $\begin{array}{l}\text { Yearly average loan balance per client as a ratio to countries' GNI } \\
\text { per capita }\end{array}$ \\
\hline \multicolumn{3}{|c|}{ MFIs' financial performance } \\
\hline PAR & Portfolio at risk & $\begin{array}{l}\text { Yearly average portfolio at risk as the ratio of MFIs' loan balances } \\
\text { past due more than } 30 \text { days and its gross loan portfolio }\end{array}$ \\
\hline ROA & Return on assets & $\begin{array}{l}\text { Yearly average of MFIs' net operating income less taxes as a ratio to } \\
\text { their average asset value }\end{array}$ \\
\hline OSS & Operational self-sufficiency & $\begin{array}{l}\text { Yearly average operational self-sufficiency as a ratio of MFIs' } \\
\text { financial revenue and their financial expenses, impairment loss and } \\
\text { operating expenses }\end{array}$ \\
\hline OPX & Operating expenses & $\begin{array}{l}\text { Yearly average operating expenses as a ratio to MFIs' gross loan } \\
\text { portfolio }\end{array}$ \\
\hline \multicolumn{3}{|c|}{ Economic development indicators } \\
\hline PHC & Poverty headcount ratio & $\begin{array}{l}\text { Percentage of population living on less than } 1.25 \text { US dollars a day } \\
\text { at } 2005 \text { international prices }\end{array}$ \\
\hline GINI & GINI coefficient & $\begin{array}{l}\text { Extent to which the distribution of income or consumption } \\
\text { expenditure among individuals or households within an economy } \\
\text { deviates from a perfectly equal distribution whereas small index } \\
\text { values indicate equality and large values imply inequality }\end{array}$ \\
\hline GDPG & GDP growth & $\begin{array}{l}\text { Annual percentage growth rate of the sum of gross value added by } \\
\text { all resident producers in the economy at market prices }\end{array}$ \\
\hline GNP & GNP per capita & $\begin{array}{l}\text { Lagged gross national income converted to international dollars } \\
\text { using purchasing power parity rates per capita }\end{array}$ \\
\hline GCF & Gross capital formation & $\begin{array}{l}\text { Lagged additions to the fixed assets of the economy plus net } \\
\text { changes in the level of inventories as percentage of GDP }\end{array}$ \\
\hline LPR & Labor participation rate & $\begin{array}{l}\text { Lagged proportion of the population aged } 15 \text { and older that is } \\
\text { economically active }\end{array}$ \\
\hline LIT & Literacy rate & $\begin{array}{l}\text { Percentage of the population age } 15 \text { and above who can, with } \\
\text { understanding, read and write a short, simple statement on their } \\
\text { everyday life including the ability to make simple arithmetic } \\
\text { calculations }\end{array}$ \\
\hline
\end{tabular}

Sources: MIX database, World Bank and own calculations.

According to the summary statistics as presented in Table 2 MFIs' performance and economic development strongly vary across the countries within our sample. Indeed, microfinance performance is found to empirically depend on the region in which MFIs operate (Vanroose \& D'Espallier, 2013) - a fact that could be explained by different development levels, cultural backgrounds and mindsets as well as economic understanding, for example with regard to loan repayment (Lopatta \& Tchikov, 2016). Our summary statistics and relevant literature, therefore, also indicate the necessity of representative empirical examinations of the causal relationship between microfinance and economic development at a global, transnational level and highlight the limited generalizability of results based on data from one single country (e.g., Eigbiremolen \& Anaduaka, 2014; Nwakanma et al, 2014; Sharma et al, 2014). 
Table 2. Summary statistics

\begin{tabular}{|c|c|c|c|c|c|c|c|}
\hline Variable & Obsv. & Mean & Std. Dev. & Minimum & Maximum & $\begin{array}{l}\text { Country } \\
\text { at Min. }\end{array}$ & $\begin{array}{c}\text { Country at } \\
\text { Max. }\end{array}$ \\
\hline NOB & 1015 & 0.0117 & 0.0193 & 0.0000 & 0.1143 & Gambia & Bangladesh \\
\hline PFB & 974 & 0.6504 & 0.2218 & 0.0464 & 1.0000 & Burundi* & $\begin{array}{c}\text { Burkina } \\
\text { Faso* }\end{array}$ \\
\hline ALB & 1031 & 0.6845 & 0.7247 & 0.0208 & 4.9342 & Mexico* & Gambia* \\
\hline PAR & 976 & 0.0555 & 0.0542 & 0.0000 & 0.4725 & Tonga* & Samoa \\
\hline ROA & 950 & -0.0032 & 0.0939 & -0.4812 & 0.2060 & Samoa & Jamaica \\
\hline OSS & 1038 & 1.0801 & 0.3482 & 0.1500 & 2.6744 & Namibia* & Burundi \\
\hline OPX & 947 & 0.3639 & 0.4307 & 0.0000 & 8.2850 & Paraguay & $\begin{array}{c}\text { Cote } \\
\text { d'Ivoire }\end{array}$ \\
\hline $\mathrm{PHC}$ & 375 & 15.4969 & 18.3384 & 0.0200 & 87.7200 & Russia & Congo \\
\hline GINI & 388 & 43.5533 & 9.6142 & 24.2400 & 67.4000 & Romania & $\begin{array}{l}\text { South } \\
\text { Africa }\end{array}$ \\
\hline GDPG & 1035 & 5.0465 & 4.2879 & -14.8000 & 46.5000 & Ukraine & Iraq \\
\hline GNI & 992 & 0.0599 & 0.0619 & -0.4194 & 0.9444 & Congo & Congo \\
\hline GCF & 974 & 0.0386 & 0.3435 & -0.8943 & 9.4482 & Nepal & Nepal \\
\hline LPR & 1008 & 0.0004 & 0.0120 & -0.0885 & 0.0722 & Ecuador & Romania \\
\hline LIT & 206 & 80.2389 & 19.4150 & 21.8229 & 99.7598 & $\begin{array}{c}\text { Burkina } \\
\text { Faso }\end{array}$ & Azerbaijan \\
\hline
\end{tabular}

* indicates countries that were not the only ones at the minimum or maximum points for the period 1995 - 2012. Still, they were at these points for the longest time within the sample period.

\subsection{Methodology}

In order to verify the causal relationship between microfinance and economic development we follow Wooldridge (2013) and pairwise estimate vector autoregressive (VAR) models for each country in our sample such as:

$$
y_{t}=\delta_{0}+\alpha_{1} y_{t-1}+\gamma_{1} z_{t-1}+\alpha_{2} y_{t-2}+\gamma_{2} z_{t-2}+\ldots
$$

and

$$
z_{t}=\eta_{0}+\beta_{1} y_{t-1}+\rho_{1} z_{t-1}+\beta_{2} y_{t-2}+\rho_{2} z_{t-2}+\ldots
$$

Here $y_{t}$ and $z_{t}$ are two series modeled in terms of their own past values and $\alpha, \beta, \gamma, \delta, \eta$, and $\rho$ are linear regression coefficients. Given past information on $y$ and $z$ the error term is expected to equal zero.

We then run Granger causality tests (Hassan et al, 2011; Nwakanma et al, 2014; Qin \& Ndiege, 2013) as the multivariate time series diagnostic approach for determining whether past values of one variable are useful for predicting another one. In particular, based on the VAR models we test whether, after controlling for past $y$, past $z$ can forecast $y_{t} . z$ thus Granger causes $y$ when

$$
\mathrm{E}\left(y_{t} \mid I_{t-1}\right) \neq \mathrm{E}\left(y_{t} \mid J_{t-1}\right)
$$

Where $I_{t-1}$ comprises of past values of $y$ and $z$, while $J_{t-1}$ only includes past values of $y$. That is, if equation (3) holds, past values of $z$ are only useful for predicting $y_{t}$ under the consideration of past values of $y$ (Wooldridge, 2013: 631).

Accordingly, in order to examine the Granger causality between microfinance and economic development we employ the following model:

Economic development $_{i, t}=\delta_{0}+\alpha_{1}$ Economic Development $_{i, t-1}+\gamma_{1}$ MFI performance pit-1 $_{+}$

$$
+\alpha_{2} \text { Economic Development }_{i, t-2}+\gamma_{2} \text { MFI performance } \text { pit,-2 }_{2}+\ldots
$$

For country $i$ in year $t$ Economic Development and MFI performance are quantified by the measures as described above. $\alpha, \gamma$, and $\delta$ are still linear regression coefficients. 


\section{Results and Discussion}

We present test results as in line with Qin et al (2013) in Table 3. In order to achieve better presentation of results we refrain from tabulating equations where due to data availability no test results could be yielded.

Table 3. Granger causality Wald tests

\begin{tabular}{|c|c|c|c|c|c|c|c|c|c|}
\hline Equation & Excluded & chi2 & $\mathrm{df}$ & Prob > chi 2 & Equation & Excluded & chi2 & $\mathrm{df}$ & Prob > chi 2 \\
\hline PHC & PFB & 3.2148 & 2 & 0.2000 & GCF & NOB & 4.5550 & 2 & 0.1030 \\
\hline PFB & PHC & 1.7597 & 2 & 0.4150 & NOB & GCF & 1.2532 & 2 & 0.5340 \\
\hline PHC & ROA & 0.8096 & 2 & 0.6670 & GCF & PFB & 7.8548 & 2 & $0.0200^{* *}$ \\
\hline ROA & PHC & 5.8084 & 2 & $0.0550^{*}$ & PFB & GCF & 8.4359 & 2 & $0.0150 * *$ \\
\hline PHC & OPX & 40.2890 & 2 & $0.0000 * * *$ & GCF & ALB & 30.9830 & 2 & $0.0000 * * *$ \\
\hline OPX & PHC & 3.9911 & 2 & 0.1360 & ALB & GCF & 1.5844 & 2 & 0.4530 \\
\hline GINI & PFB & 2.7608 & 2 & 0.2510 & GCF & PAR & 1.5247 & 2 & 0.4670 \\
\hline PFB & GINI & 22.8610 & 2 & $0.0000 * * *$ & PAR & GCF & 182.6700 & 2 & $0.0000 * * *$ \\
\hline GINI & ROA & 7.7503 & 2 & $0.0210 * *$ & GCF & ROA & 30.3670 & 2 & $0.0000 * * *$ \\
\hline ROA & GINI & 32.7740 & 2 & $0.0000 * * *$ & ROA & GCF & 10.8280 & 2 & $0.0040 * * *$ \\
\hline GINI & OPX & 6.0274 & 2 & $0.0490 * *$ & GCF & OSS & 12.8260 & 2 & $0.0020^{* * *}$ \\
\hline OPX & GINI & 37.7250 & 2 & $0.0000 * * *$ & OSS & GCF & 7.0404 & 2 & $0.0300^{* *}$ \\
\hline GDPG & NOB & 0.7811 & 2 & 0.6770 & GCF & OPX & 0.7179 & 2 & 0.6980 \\
\hline NOB & GDPG & 3.2371 & 2 & 0.1980 & OPX & GCF & 167.4200 & 2 & $0.0000 * * *$ \\
\hline GDPG & PFB & 19.7150 & 2 & $0.0000 * * *$ & LPR & NOB & 16.8710 & 2 & $0.0000 * * *$ \\
\hline PFB & GDPG & 4.3801 & 2 & 0.1120 & NOB & LPR & 0.0753 & 2 & 0.9630 \\
\hline GDPG & ALB & 230.8500 & 2 & $0.0000 * * *$ & LPR & PFB & 11.8860 & 2 & $0.0030 * * *$ \\
\hline ALB & GDPG & 6.1759 & 2 & $0.0460 * *$ & PFB & LPR & 2.9403 & 2 & 0.2300 \\
\hline GDPG & PAR & 0.7202 & 2 & 0.6980 & LPR & ALB & 166.6200 & 2 & $0.0000 * * *$ \\
\hline PAR & GDPG & 4.7841 & 2 & $0.0910^{*}$ & ALB & LPR & 34.0980 & 2 & $0.0000 * * *$ \\
\hline GDPG & ROA & 0.8491 & 2 & 0.6540 & LPR & PAR & 1.0429 & 2 & 0.5940 \\
\hline ROA & GDPG & 4.4964 & 2 & 0.1060 & PAR & LPR & 0.7184 & 2 & 0.6980 \\
\hline GDPG & OSS & 11.5710 & 2 & $0.0030 * * *$ & LPR & ROA & 5.2649 & 2 & $0.0720 *$ \\
\hline OSS & GDPG & 4.5997 & 2 & 0.1000 & ROA & LPR & 26.2830 & 2 & $0.0000 * * *$ \\
\hline GDPG & OPX & 14.7900 & 2 & $0.0010 * * *$ & LPR & OSS & 4.0555 & 2 & 0.1320 \\
\hline OPX & GDPG & 66.6270 & 2 & $0.0000^{* * *}$ & OSS & LPR & 0.6162 & 2 & 0.7350 \\
\hline GNI & NOB & 1.6708 & 2 & 0.4340 & LPR & OSS & 4.0555 & 2 & 0.1320 \\
\hline NOB & GNI & 58.0740 & 2 & $0.0000 * * *$ & OSS & LPR & 0.6162 & 2 & 0.7350 \\
\hline GNI & PFB & 56.7640 & 2 & $0.0000 * * *$ & LIT & ALB & $1.3 e+24$ & 1 & $0.0000 * * *$ \\
\hline PFB & GNI & 8.9347 & 2 & $0.0110 * *$ & & & & & \\
\hline GNI & ALB & 12.7140 & 2 & $0.0020 * * *$ & & & & & \\
\hline ALB & GNI & 213.6700 & 2 & $0.0000 * * *$ & & & & & \\
\hline GNI & PAR & 1.5807 & 2 & 0.4540 & & & & & \\
\hline PAR & GNI & 19.1870 & 2 & $0.0000^{* * *}$ & & & & & \\
\hline GNI & OSS & 1.0037 & 2 & 0.6050 & & & & & \\
\hline OSS & GNI & 0.3369 & 2 & 0.8450 & & & & & \\
\hline
\end{tabular}

The zero hypothesis in Granger causality Wald tests aims at proving that excluded variables do not Granger cause the corresponding equation variables.

$*($ Prob $>$ chi 2$)<0.1, * *($ Prob $>$ chi 2$)<0.05, * * *($ Prob $>$ chi 2$)<0.01$. 
Significant Granger tests yield an unidirectional causal relationship of MFIs' profitability as measured by their return on assets (ROA) as well as MFIs' efficiency as measured by their operating expenses (OPX) to country-level poverty headcount ratios (PHC). In particular, test results indicate that Granger causality is given from ROA to poverty and from poverty to OPX. The interrelation between percentage of female borrowers (PFB) and income inequality (GINI) is also only unidirectional causal, i.e. PFB Granger causes GINI but GINI does not (significantly) Granger cause PFB. Significant bidirectional Granger causality is then found between income inequality and both MFIs' ROA as well as operating expenses. Also, the relationship of MFIs' percentage of female borrowers and GDP growth (GDPG) is only shown to be one-way Granger causal with causality going from GDPG to PFB. In contrast, the interaction between average loan balances (ALB) and GDP growth is found to be two-way causal. Our analyses then point to unidirectional Granger causality of MFIs' portfolio quality as measured by portfolio at risk (PAR) to GDP growth and from GDP growth to MFIs' operational self-sufficiency (OSS). The relationship between MFIs' operating expenses and GDP growth is, however, found to be two-way Granger causal. A further unidirectional causal relationship is found for MFIs' number of borrowers (NOB) and GNI per capita with NOB Granger causing GNI. On the other hand, both MFIs' percentage of female borrowers (PFB) and average loan balances (ALB) as MFIs' social performance measures are shown to bidirectional causally interact with GNI per capita. Our test results then point to unidirectional Granger causality of portfolio at risk to GNI per capita. The interrelation between percentage of female borrowers (PFB) and gross capital formation (GCF) is also shown to be bidirectional causal. In contrast, ALB and gross capital formation are found to interact unidirectional causal with GCF Granger causing MFIs' average loan balances. Then, while our tests yield significant bidirectional Granger causality between ROA and OSS and gross capital, Granger causality of MFIs' portfolio at risk (PAR) as well as operating expenses (OPX) to GCF is only unidirectional. The relationships of number of borrowers (NOB) as well as percentage of female borrowers (PFB) and labor participation (LPR) are also unidirectional causal whereas results indicate that labor participation rates Granger cause MFIs' social performance. The interrelations between average loan balances (ALB) as well as MFIs' return on assets and labor participation are, however, found to be two-way causal. With regard to literacy rates (LIT) due to limited availability of time series data only one significant result could be obtained, namely the unidirectional causality of LIT to average loan balances.

Our analyses thus indicate that MFIs' social performance in terms of percentage of female borrowers and average loan balances is bidirectional causally related with economic development as measured by GNI per capita. Our results further confirm current research that has verified unidirectional Granger causality from economic development to microfinance (Eigbiremolen \& Anaduaka, 2014; Nwakanma et al, 2014; Sharma et al, 2014). Then, the two-way causal relationship between MFIs' average loan balances as a proxy of microfinance clients' poverty levels (Rosenberg, 2009) and labor participation highlights the strong interaction microfinance has with (micro-)entrepreneurship (Morduch, 1999). On the other hand, the fact that the Granger tests yield no evidence on causality between number of borrowers and the majority of economic development indicators confirms Lopatta and Tchikov (2016) who state that microfinance should not be about quantity but rather about quality in terms of more female clients and small loan amounts.

The Granger tests with regard to the causal interrelations of MFIs' social and financial performance indicators and gross capital formation also confirm current research that has demonstrated the influence microfinance has on capital accumulation (Hassan et al, 2011; Kamath, 2009). Still, as our results refer to effects between macroeconomic development indicators and MFI-specific performance they extend the perspective of existing studies that have examined the relationship between aggregate microloan portfolios and gross capital or GDP (Maksudova, 2010; Nwakanma et al, 2014).

That, according to our results, MFIs' profitability and efficiency as measured by return on assets and operating expenses causally interact with both economic development and income inequality, then confirms the ambiguousness of the effects MFIs' financial performance has on their long-term objectives as in line with current research (e.g., Cull et al, 2007; Morduch, 1999). The findings further suggest that MFIs' financial performance might contribute to financial systems and economic development but it also might be counterproductive for their clients' welfare and underline the importance of the 'mission drift' debate in current microfinance literature, i.e. the debate on MFIs' re-focus from the support of their poor clients towards profitability.

\section{Conclusion}

Within this study we have explored an underexamined though highly relevant research field - the causality between microfinance and economic development. Our Granger causality tests offer novel evidence on the causal role of microfinance in the economic development process. We add to current literature by being the first, to our knowledge, 
to empirically differentiate between MFIs' social and financial performance and to verify their causal interaction with economic development. Furthermore, we extend current research by considering several economic development indicators that might be influenced by the concept of microfinance. We are thus able to validate the causal interrelation of microfinance with labor participation and entrepreneurship. Then, we present results that base on a large and representative transnational dataset that allows their cross-country generalizability.

The certainty about this causal relationship contributes to developing purposeful and progressive action to promote economic development and poverty alleviation. Based on our results, MFIs, development programs and socially responsible investors should align their social and financial performance strategies in order to achieve their 'double bottom line' targets. On the one hand, the bidirectional causality between MFIs' social performance, i.e. their percentage of female borrowers as well as average loan balances and economic development as well as labor participation shows that microfinance sustainably contributes to economic development. On the other hand, according to our results this microfinance-induced growth leads to a better social performance of MFIs and in fact suggests a win-win solution within the microfinance industry. MFIs' financial performance, i.e. return on assets and operating expenses, is, however, found to ambiguously interrelate with economic development, poverty alleviation and income inequality. Despite the capital effects microfinance might have on developing countries' economies MFIs should consciously steer their financial performance to a status that does not jeopardize their clients' welfare.

Our findings have also implications for microfinance theory and research. Future empirical analyses should consider them and statistically account for the causal interaction between microfinance and economic development. Future research should then overcome the limitations of our study due to restricted data availability and utilize additional (lagged) development indicators in order to better assess the interrelations of microfinance and economic development. Further country- and/or region-level analyses should then be conducted in order to enable deriving targeted measures aimed at concentrated economic development and poverty reduction.

\section{References}

Ahlin, C., Lin, J., \& Maio, M. (2011). Where does microfinance flourish: Microfinance institution performance in macroeconomic context. Journal of Development Economics, 95(2), 105-120. https://doi.org/10.1016/j.jdeveco.2010.04.004

Armendáriz, B., \& Morduch, J. (2010). The Economics of Microfinance. Cambridge: MIT Press.

Assefa, E., Hermes, N., \& Meesters, A. (2013). Competition and the performance of microfinance institutions. Applied Financial Economics, 23(9), 767-782. https://doi.org/10.1080/09603107.2012.754541

Awojobi, O., \& Bein, M. (2011). Microfinancing for poverty reduction and economic development: A case for Nigeria. International Research Journal of Finance and Economics, 72, 159-168.

Bank for International Settlements, Basel Committee on Banking Supervision. (2010). Microfinance activities and the core principles for effective banking supervision. Retrieved from http://www.bis.org/publ/bcbs175.pdf

Cull, R., Demirgüç-Kunt, A., \& Morduch, J. (2007). Financial performance and outreach: A global analysis of $\begin{array}{llll}\text { leading microbanks. } & \text { Economic Journal, }\end{array}$ https://doi.org/10.1111/j.1468-0297.2007.02017.x

Cull, R., Navajas, S., Nishida, I., \& Zeiler, R. (2015). A new index of the business environment for microfinance. World Development, 70, 357-388. https://doi.org/10.1016/j.worlddev.2014.11.023

Eigbiremolen, D., \& Anaduaka, U. (2014). The place of microfinance in today's economy: Further evidence from Nigeria. International Journal of Academic Research in Economics and Management Sciences, 3(1), 12-22. https://doi.org/10.6007/IJAREMS/v3-i1/551

Granger, C. W. J. (1969). Investigating causal relations by econometric models and cross-spectral methods. Econometrica, 37(3), 424-438. https://doi.org/10.2307/1912791

Hassan, M., Sanchez, B., \& Yu, J. (2011). Financial development and economic growth: New evidence from panel data. The Quarterly Review of Economics and Finance, 51(1), 88-104. https://doi.org/10.1016/j.qref.2010.09.001

Hudon, M., \& Périlleux, A. (2014). Surplus distribution and characteristics of social enterprises: Evidence from microfinance. The Quarterly Review of Economics and Finance, 54(2), 147-157. https://dx.doi.org/10.1016/j.qref.2013.10.002

Imai, K. S., Gaiha, R., Thapa, G., \& Annim, S. K. (2012). Microfinance and poverty: A macro perspective. World 
Development, 40(8), 1675-1689. https://doi.org//10.1016/j.worlddev.2012.04.013

Islam, A., Nguyen, C., \& Smyth, R. (2015). Does microfinance change informal lending in village economies? Evidence from Bangladesh. Journal of Banking and Finance, 50, 141-156. https://doi.org/10.1016/j.jbankfin.2014.10.001

Kamath, K. V. (2009). Microfinance and economic growth: Reflections on Indian experience. In I. Matthäus-Maier, \& J. D. Pischke (Eds.), New partnerships for innovation in microfinance (pp. 81-84). Berlin: Springer.

King, R. G., \& Levine, R. (1993). Finance and growth: Schumpeter might be right. Quarterly Journal of Economics, 108(3), 717-736. https://doi.org/10.2307/2118406

Lopatta, K., \& Tchikov, M. (2016). Do microfinance institutions fulfil their promise? Evidence from cross-country data. Applied Economics, 48(18), 1655-1677. https://doi.org/10.1080/00036846.2015.1105924

Maksudova, N. (2010). Macroeconomics of microfinance: How do the channels work? CERGE-EI Working Paper Series No. 423.

Morduch, J. (1999). The microfinance promise. Journal of Economic Literature, 37(4), 1569-1614. https://doi.org/10.1257/jel.37.4.1569

Nwakanma, P. C., Nnamdi, I. S., \& Omojefe, G. O. (2014). From rural to microfinance banking: Contributions of micro credits to Nigeria's economic growth - an ARDL approach. International Journal of Financial Research, 5(3), 73-85. https://dx.doi.org/10.5430/ijfr.v5n3p73

Prior, F., \& Argandoña, A. (2009). Credit accessibility and corporate social responsibility in financial institutions: The case of microfinance. Business Ethics: A European Review, 18(4), 349-363. https://dx.doi.org/10.1111/j.1467-8608.2009.01568.x

Qin, X., \& Ndiege, B. O. (2013). Role of financial development in economic growth: Evidence from savings and credits cooperative societies in Tanzania. International Journal of Financial Research, 4(2), 115-125. https://dx.doi.org/10.5430/ijfr.v4n2p115

Rajbanshi, R., Huang. M., \& Wydick, B. (2015). Measuring microfinance: Assessing the conflict between practitioners and researchers with evidence from Nepal. World Development, 68, 30-47. https://dx.doi.org/10.1016/j.worlddev.2014.11.011

Rosenberg, R. (2009). Measuring results of microfinance institutions - minimum indicators that donors and investors should track. A technical guide, Consultative Group to Assist the Poor CGAP. Washington, World Bank.

Schicks, J. (2014). Over-indebtedness in microfinance - an empirical analysis of related factors on the borrower level. World Development, 54, 301-324. https://doi.org/10.1016/j.worlddev.2013.08.009.

Schumpeter, J. A. (1955). The Theory of Economic Development. Cambridge: Harvard University Press.

Sharma, G. L., Himanshu, P., \& Hartika, C. (2014). An empirical analysis of causal relationship between micro-loans and various economic indicators of India. International Journal of Engineering and Management Sciences, 5(2), 102-108. Retrieved from http://www.scienceandnature.org/IJEMS-Vol5(2)-Apr2014/IJEMS\%20Vol5(2)-7.pdf

Tonelli, M., \& Dalglish, C. (2011). A socially responsible model of micro-credit delivery to support sustainable community development in emerging economies. QUT Business School: Queensland University of Technology.

Vanroose, A., \& D'Espallier, B. (2013). Do microfinance institutions accomplish their mission? Evidence from the relationship between traditional financial sector development and microfinance institutions' outreach and performance. Applied Economics, 45(15), 1965-1982. https://doi.org/10.1080/00036846.2011.641932

Wooldridge, J. M. (2013). Introductory econometrics: A modern approach. 5th edition, Mason, Ohio: South Western Educational Publishing. 